\title{
IN VITRO SUSCEPTIBILITY OF ISOLATED SHIGELLA FLEXNERI AND SHIGELLA DYSENTERIAE TO THE ETHANOLIC EXTRACTS OF TRACHYSPERMUM AMMI AND PEGANUM HARMALA
}

\author{
IBRAHIM SIDDIG HAMID1, IKRAM MOHAMED ELTAYEB ${ }^{1^{*}}$
}

University of medical sciences and technology (UMST)

Email: kramela_07@yahoo.com

Received: 29 Aug 2018 Revised and Accepted: 04 Dec 2018

\section{ABSTRACT}

Objective: This study represents the first attempt to investigate the antimicrobial activity of Peganum harmala, and Trachyspermum ammi seeds extract against the isolated bacillary dysentery-causing microorganisms.

Methods: T. ammi and P. harmala were extracted by $96 \%$ ethanol using Soxhlet apparatus. The extracts were screened for their phytochemical constituents. Their antimicrobial activity against the isolated dysentery-causing microorganisms was evaluated using the agar diffusion method.

Results: The antimicrobial activity result showed that, the two isolated bacteria, Shigella flexneri, and Shigella dysenteriae were found to be sensitive to the extract of T. ammi seed with inhibition zones up to $25 \mathrm{~mm}$, compared to the inhibition zone of 20 mm produced by Gentamycin standard drug, this is mainly due to the presence of the different phytochemical in the extract such as tannin, flavonoids, terpenoids which are well known for their antimicrobial effects. The two isolated bacteria were found to be insensitive (zero mm) to P. harmala extract, Amoxicillin, and Amoclan (Amoxicillin+clavulanic acid) standard drugs, this is due to the fact that, the phytochemicals constituents of $P$. harmala possess the antagonistic effect to each other's. Addition to; these bacteria became resistant to both Amoxicillin and Amoclan.

Conclusion: From the results it concludes, T. ammi seeds extract had a considerable level of antimicrobial activity against bacillary dysenterycausing microorganisms resistant to Amoxicillin and Amoxicillin+clavulanic acid drugs.

Keywords: Trachyspermu, ammi, Peganum, Harmala, Shigella, Flexneri, Dysenetry

(C) 2019 The Authors. Published by Innovare Academic Sciences Pvt Ltd. This is an open-access article under the CC BY license (http://creativecommons.org/licenses/by/4.0/D DOI: http://dx.doi.org/10.22159/ijpps.2019v11i1.29411

\section{INTRODUCTION}

The medicinal plants are very important to the health of individuals and communities worldwide; this is mainly due to that, most of the drugs derived from herbs are free of side effects or reactions $[1,2]$. The herbs have medicinal quality provide rational means for the treatment of many diseases, which are considered of difficult cure [3].

In Sudan the mixtures of Peganum harmala and Trachyspermum ammi seeds are traditionally used for the treatment of bacillary dysentery. Trachyspermum ammi commonly known as Ajwain is a very valued medicinally plant belongs to Apiaceae family. It is an abundantly branched annual herb [4]. It used traditionally for treatment of gastrointestinal ailments, lack of appetite and bronchial problems [5] as well used as antiseptic, antipyretic, febrifugal and in the treatment of typhoid fever [6,7] as antimicrobial agent [8], digestive stimulant [9], antihypertensive, hepatoprotective, antispasmodic, broncho-dilating [10], antilithiasis, diuretic [11], abortifacient [12], galactogogic [13], antiplatelet-aggregatory [14], anti-inflammatory [15], antitussive [16], antimalarial [17], gestroprotective [18], anthelmintic [19], detoxification of aflatoxins [20], and ameliorative effects [21].

Peganum harmala belongs to the family Zygophyllaceae is a perennial plant growing up to $0.8 \mathrm{~m}$ [22] has been reported to have an antibacterial activity [23], an abortifacient [24], and in large quantities, it can reduce spermatogenesis and male fertility in rats [25]. It also used to treat depression, recurring fevers [26], kill algae, bacteria, intestinal parasites and molds [27]. Its endogenous alkaloids have been proven to be involved in Parkinson's disease [28].

Bacillary dysentery, which is caused by invasive bacteria mainly by one or more types of Shigella species such as Shigella dysenteri and shigella flexneri [29] is mainly found in hot countries like Sudan. Poor hygiene and sanitation increase incidence of dysentery by spreading microorganism causing it through food and water which are contaminated by human feces [30].
Bacillary dysentery symptoms include sudden onset of high fever and chills, abdominal pain, cramps and bloating, the urgency to pass stool, weight loss, and dehydration. The symptoms start within 2 to $10 \mathrm{~d}$, and if left untreated it can lead to serious complications include delirium, convulsions, and coma. A serious infection can be fatal within $24 \mathrm{~h} \mathrm{[31].} \mathrm{is} \mathrm{The} \mathrm{principal} \mathrm{aim} \mathrm{of} \mathrm{this} \mathrm{study} \mathrm{was} \mathrm{to} \mathrm{investigate} \mathrm{the}$ antimicrobial activity of Peganum harmala and Trachyspermum ammi seeds extracts against isolated Shigella flexneri and Shigella dysenteriae, bacillary dysentery-causing microorganism (Shigellosis) whereas these microorganisms are becoming resistant to antimicrobial drugs, addition too many side effects caused by synthetic drugs.

\section{MATERIALS AND METHODS}

Plant material collection and preparation

Dried seeds of P. harmala and T. ammi were collected from the botanical garden at Omdurman area, Sudan, and authenticated by taxonomist at the Department of Aromatic and Medicinal Plants Research in the Sudan National Research Center. The voucher specimens identified as IBRAHIM (3), December-2017) and; IBRAHIM (4), December-2017 were deposited at the Department of Pharmacognosy, Faculty of Pharmacy, University of Medical Science and Technology.

\section{Preparation of $P$. harmala and T. ammi extracts}

The coarsely powdered seeds of P. harmala and T. ammi were extracted with $96 \%$ ethanol using Soxhlet extractor apparatus. Extraction was carried for six to eight hours till the color of solvent at the last siphoning time returned colorless. The solvent was evaporated under reduced pressure using a rotary evaporator apparatus, then the extracts were complete dryness, and the percentage yields were calculated. The extracts stored at $4{ }^{\circ} \mathrm{C}$ for further investigation.

\section{Phytochemical screening test}

The phytochemical constituents of the extracts were detected using the standard procedure as described by Trease and Evans [32] and Sofowora [33]. 


\section{Collection and preparation of the isolated bacteria}

Feces samples were collected from Yastabsheron Hospital/Sudan and the bacteria were isolated and identified by a microbiologist at the National Centre for Research/Sudan. The isolated bacteria were cultured in agar media and incubated for $24 \mathrm{~h}$ to allow bacterial growth and then the antimicrobial test was conducted.

\section{Antimicrobial bioassay}

Antimicrobial testing was carried out using the agar diffusion method with some minor modification. Nutrient agar medium was used as a growth medium and was placed in an autoclave using the following conditions $37{ }^{\circ} \mathrm{C}$ and $15 \mathrm{lbs}$ pressure for $15 \mathrm{~min}$ for sterilization. The medium $(20 \mathrm{ml})$ was then poured in a Petri dish under aseptic conditions and $(0.2 \mathrm{ml})$ of the intended microorganism was introduced into the prepared medium. After the medium had solidified, discs containing the prepared extracts were added in each plate. The diameters $(\mathrm{mm})$ of the inhibition zones were measured [34]. The experiment was repeated with serial dilution of plant extracts $(100$ $\mathrm{mg} / \mathrm{ml}, 50 \mathrm{mg} / \mathrm{ml}, 25 \mathrm{mg} / \mathrm{ml}, 12.5 \mathrm{mg} / \mathrm{ml}$ and $6.25 \% \mathrm{mg} / \mathrm{ml}$ ) to determine the minimum inhibitory concentration (MIC) of the extracts. All experiments were conducted in triplicate.

\section{RESULTS}

\section{Percentage Yields}

T. ammi and P. harmala seeds extract produced by using of $96 \%$ ethanol were found to be of slightly difference in their percentages yields (table 1).

\section{Phytochemical screening}

The phytochemical screening of T. ammi and P. harmala extracts (table 2) revealed the presence of saponins, tannins, cardiac glycosides, terpenoids, steroids and reducing sugars in both plants. The alkaloids are present in the extract of and P. harmala.

\section{Antimicrobial activity}

The antimicrobial activity of $T$. ammi seeds extracts, against the isolated microorganisms (fig. 1 ) showed the highest activity $(25,24$ $\mathrm{mm}$ ) against the two tested bacteria, it was slightly highest against Shigella flexneri than Shigella dysenteriae. Whereas, the two bacteria were found to be insensitive to the P. harmala extract, Amoxicillin, and Amoxicillin+Clavulanic acid. Gentamycin showed the same and high activity $(20 \mathrm{~mm})$ against both bacteria.

Table 1: Percentage yield of T. ammi and P. harmala seeds extracts

\begin{tabular}{lll}
\hline Plant extract & Weight of sample & Weight of extract \\
\hline T. ammi & $100 \mathrm{~g}$ & 33.07 \\
P. harmala & $100 \mathrm{~g}$ & 32.78 \\
\hline
\end{tabular}

Table 2: Qualitative phytochemical screening of T. ammi and P. harmala seeds extracts

\begin{tabular}{lll}
\hline Secondary metabolites & T. ammi & P. harmala \\
\hline Alkaloids & -ve & $+\mathrm{ve}$ \\
Saponins & $+\mathrm{ve}$ & $+\mathrm{ve}$ \\
Tannins & $+\mathrm{ve}$ & $+\mathrm{ve}$ \\
Ccardiac glycoside & $-\mathrm{ve}$ & $+\mathrm{ve}$ \\
Flavonoids & $+\mathrm{ve}$ & $-\mathrm{ve}$ \\
Sterols & $+\mathrm{ve}$ & $+\mathrm{ve}$ \\
Tterpenoids & $+\mathrm{ve}$ & $+\mathrm{ve}$ \\
Reducing sugars & -ve & $+\mathrm{ve}$ \\
Compound reducing sugars & & $-\mathrm{ve}$ \\
\hline
\end{tabular}

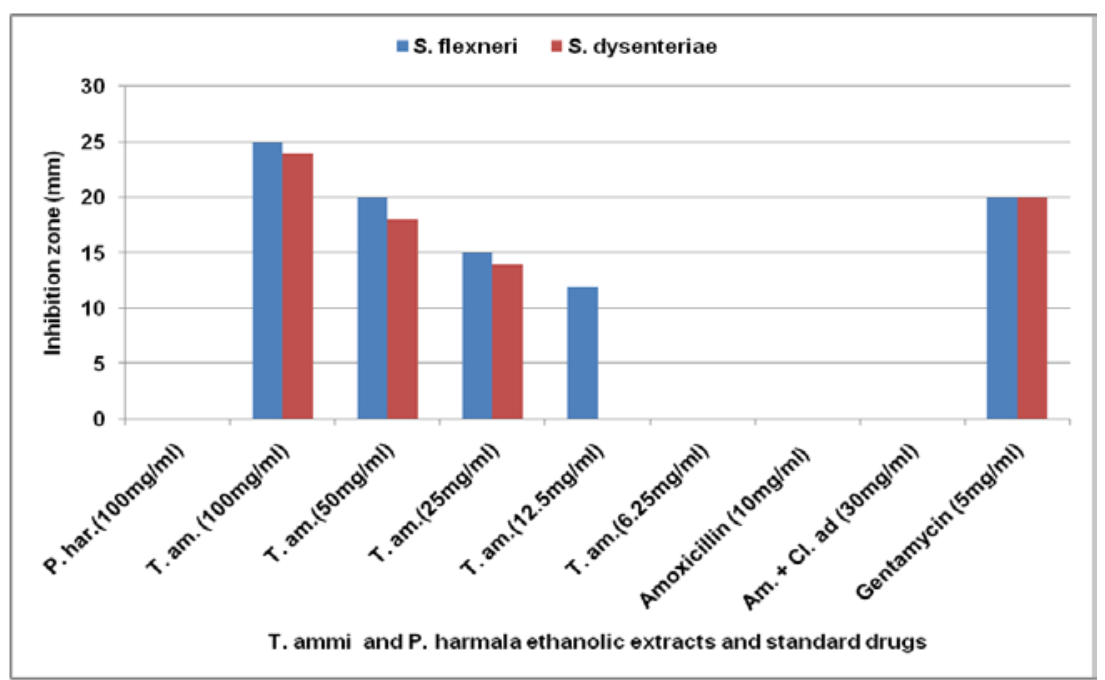

Fig. 1: Antimicrobial activity of T. ammi and P. harmala seeds ethanolic extracts against isolated bacteria, P. har $=P$. harmala, T. am. $=T$. ammict, Am.+Cl. ad= Amoxicillin+Clavulanic acid. The values represent the mean of the three determinants

\section{DISCUSSION}

The medicinal plants contain a wide range of active secondary metabolites which may include synergies one another to give a beneficial pharmacological effect [1]. The preliminary phytochemical analysis of T. ammi and P. harmala seeds (table 2) revealed the presence of saponins, tannins, cardiac glycosides, terpenoids, steroids and reducing sugars in both assessed plants as reported in 
these two plants $[35,36]$. Additions to alkaloids were found in the extract of $P$. harmala compatible with their present in plant [36]. Flavonoids show the negative result which is incompatible with the previous study [36], due to different in climate and cultivation process of the plant sample.

Regarding the antimicrobial activity results of T. ammi and P. harmala seeds extracts against the isolated bacillary dysentery-causing bacteria (fig. 1), both isolated bacteria; Shigella dysenteriae and Shigella flexneri were found to be highly sensitive $(24-25 \mathrm{~mm})$ towards the extract of $T$. ammi with MIC value of $25 \mathrm{mg} / \mathrm{ml}$ against Sh. dysenteriae and 25 $\mathrm{mg} / \mathrm{ml}$ against Sh. flexneri. On the other hand, $P$. harmala seeds extract was found to be inactive against the two tested bacteria

It is noteworthy that the isolated Sh. dysenteriae and Sh. flexneri were found to be resistant towards both Amoxicillin and Amoxicillin+clavulanic acid standard drugs, and highly sensitive towards Gentamycin (fig. 1). The activity order was higher in $T$. ammi extract (24-25 $\mathrm{mm}$ ) than that of Gentamycin standard drug $(20 \mathrm{~mm})$ against both bacteria.

The results of T. ammi extract against two assessed bacteria, which were well known for their causing of bacillary dysentery [29] is comply with antimicrobial activity of the plant [9] and confirm it is traditionally used for the treatment of bacillary dysentery $[5,6]$. However, the result of $\mathrm{P}$. harmala extract against both bacteria is incompatible with it is an antibacterial effect [24] which is in line with the specify effect of the plant against microorganisms and agrees with the report that the effect of an agent varies with target species [37].

Although the two assessed plants were nearly having similarity in general phytochemicals (table 2); they appeared to be of highly different in their activity towards the tested bacteria (fig. 1), this is mainly due to the fact that, compounds found in each plant are the difference. Addition to that, the tested bacteria were also found to differ in their susceptibility towards the three standard drugs used (fig. 1), this is in agreement with the report that the effect of an agent varies with target species [37].

\section{CONCLUSION}

The study has revealed that $T$. ammi ethanolic extract possessed antimicrobial activity as stated in the literature. From the results, it appeared that Amoxicillin and Amoxicillin+clavulanic acid were completely insensitive for both Shigella flexneri and Shigella dysenteriae. T. ammi extract exhibited the highest antimicrobial activity, which was higher than that of Gentamycin. This justified their use as antimicrobial in Sudanese traditional medicine.

\section{ACKNOWLEDGMENT}

Authors are thankful to Yastabshiron Hospital/Sudan for providing the stool infected sample.

\section{AUTHORS CONTRIBUTIONS}

The experimental part of the work and writing of the manuscript was done by the first author Mr. Ibrahim Siddig Hamid. Design of the work, interpretation of data and correction of the manuscript was done by Dr. Ikram Mohamed Eltayeb.

\section{CONFLICT OF INTERESTS}

\section{Declared none}

\section{REFERENCES}

1. Arunkumar K, KR Chandrashekar. Phytochemical evaluation and in vitro antimicrobial and antioxidant studies of leaf and stem bark extracts of Polyalthia fragrans (dalz.) bedd-an endemic species of Western ghats. Int J Pharm Pharm Sci 2017;9:20-4.

2. Benahmed Bouhafsoun A, Djied S, Mouzaz F, Kaid Harche M. Phytochemical composition and in vitro antioxidant activity of Chamaerops humilis L. extracts. Int J Pharm Pharm Sci 2013;5:741-4.

3. Al-khazraji S, Khalil I. Antinociceptive activity of the alcoholic extract of trachyspermum ammi (L) (Ajwain) in rats. Halabja University J 2016;1:423-44.
4. Mahtab Alam Khan. Introduction and importance of medicinal plant and herbs. Published by Zahid; 2016.

5. Singh I, Singh VP. Antifungal properties of aqueous and organic solution extracts of seed plants against Aspergillus flavus and $A$. niger. Phytomorphology 2000;50:151-7.

6. Bairwa R, Sodha RS, Rajawat BS. Trachyspermum ammi reviews. Pharmacognosy 2012;6:56.

7. Choudhury S, Ahmed R, Kanjilal PB, Leclercq PA. Composition of the seed oil of Trachyspermum ammi (L.) sprague from Northeast India. J Essential Oil Res 1998;10:588-90.

8. Sivropoulou A, Papanikolaou E, Nilolaou C, Kokkini S, Lanaras $\mathrm{T}$, Arsenakis M. Antimicrobial and cytotoxic activities of origanium essential oils. J Agric Food Chem 1996;44:1202-5.

9. Vasudevan K, Vembar S, Veeraraghavan K, Haranath PS. Influence of intragastric perfusion of aqueous spice extracts on acid secretion in anesthetized albino rats. Indian J Gastroenterol: Official J Indian Soc Gastroenterol 1999;19:53-6.

10. Gilani AH, Jabeen Q, Ghayur MN, Janbaz KH, Akhtar MS. Studies on the antihypertensive, antispasmodic, bronchodilator and hepatoprotective activities of the carum copticum seed extract. J Ethnopharmacol 2005;98:127-35.

11. Ahsan SK, Shah AH, Tanira MOM, Ahmad MS, Tariq M, Ageel AM. Studies on some herbal drugs used against kidney stones in Saudi folk medicine. Fitoterapia 1990;61:435-8.

12. Nath D, Sethi N, Srivastava S, Jain AK, Srivastava R. Survey on indigenous medicinal plants used for abortion in some districts of Uttar Pradesh. Fitoterapia 1997;68:223-5.

13. Kaur H. Estrogenic activity of some herbal galactagogue constituents. Indian J Animal Nutr 1998;15:232-4.

14. Srivastava KC. Extract of a spice-omum (Trachyspermum ammi)-shows antiaggregatory effects and alters arachidonic acid metabolism in human platelets. Prostaglandins Leukotrienes Essent Fatty Acids 1988;33:1-6.

15. Thangam C, Dhananjayan R. Antiinflammatory potential of the seeds of carum copticum linn. Indian J Pharmacol 2003;35:388-91.

16. Boskabady MH, Jandaghi P, Kiani S, Hasanzadeh L. Antitussive effect of Carum copticum in guinea pigs.J Ethnopharmacol 2005;97:79-82.

17. Mathew N, Misra-Bhattacharya S, Perumal V, Muthuswamy K Antifilarial lead molecules isolated from trachyspermum ammi. Molecules 2008;13:2156-68.

18. Ramaswamy S, Sengottuvelu S, Sherief SH, Jaikumar S, Saravanan R, Prasadkumar C, et al. Gastroprotective activity of ethanolic extract of Trachyspermum ammi fruit. Int J Pharma Bio Sci 2010;1:1-15.

19. Priestley CM, Williamson EM, Wafford KA, Sattelle DB. Thymol, a constituent of thyme essential oil, is a positive allosteric modulator of human GABAA receptors and a homeoligomeric GABA receptor from Drosophila melanogaster. Br J Pharmacol 2003;140:1363-72.

20. Velazhahan R, Vijayanandraj S, Vijayasamundeeswari A, Paranidharan V, Samiyappan R, Iwamoto T, et al. Detoxification of aflatoxins by seed extracts of the medicinal plant, Trachyspermum ammi (L.) Sprague ex Turrill-structural analysis and biological toxicity of degradation product of aflatoxin G1. Food Control 2010;21:719-25.

21. Anilakumar KR, Saritha V, Khanum F, Bawa A. SAmeliorative effect of ajwain extract on hexachlorocyclohexane-induced lipid peroxidation in rat liver. Food Chem Toxicol 2009;47:279-82.

22. http://www.ars-grin.gov/cgi-bin/npgs/html/taxon.Peganum harmala information from NPGS/GRIN [Last accessed on 17 Feb 2008.

23. Prashanth D, John S. Antibacterial activity of peganum harmala. Fitoterapia 1999;70:438-9.

24. Panda H. Book of herbs cultivation and medicinal uses. Delhi: National Institute of Industrial Research; 2000. p. 435.

25. El-Dwairi QA, Banihani SM. Histo-functional effects of Peganum harmala on male rat's spermatogenesis and fertility. Neurol Endocrinol Lett 2007;28:305-10.

26. Monsef HR, Ghobadi A, Iranshahi M, Abdollahi M. Antinociceptive effects of peganum harmala L. alkaloid extract on mouse formalin test. J Pharm Pharm Sci 2004;7:65-9.

27. M Abdolahi. Peganum harmala L. alkaloid extract on mouse formalin test. J Pharm Pharm Sci 2008;7:65-9. 
28. Splettstoesser F, Bonnet U, Wiemann M, Bingmann D Busselberg D. Modulation of voltage-gated channel currents by harmaline and harmane. Br J Pharmacol 2005;144:52-8.

29. Azam Fatahi, Ali Ajami, Mojgan Bozorgzad, Shahram Nekoeian, Atefeh Khazeni. A comparison between culture and multiplex PCR for detection and identification of Shigella species in patients with Shigellosis from Isfahan province in 2014-2015. J Med Microbiol Infection Diseases 2015;3:23-8.

30. D Riding. Acute bacillary dysentery in khartoum province, sudan, with special reference to bacteriophage treatment: bacteriological investigation. J Hygiene 1930;30:387-401.

31. Hale TL, Keusch Gt. Shigella. In: Baron S. Editor. Medica Microbiology. $4^{\text {th }}$ Edition. Galveston (Tx): University of Texas Medical Branch at Galveston: Chap2; 1996.

32. Evans, William Charles. Trease and Evans' Pharmacognosy. 11 edition. Elsevier Health Sciences; 2009.
33. Sofowora A. Recent trends in research into African medicinal plants. J Ethnopharmacol 1993;38:197-208.

34. Wayne, Pensilvania document M100-S9. Performance standards for antimicrobial susceptibility testing. Vol. 19 National Committee for Clinical Laboratory Standards (NCCLS); 1999.

35. Ishikawa T, Sega Y, Kitajima J. Water-soluble constituents of ajowan. Chem Pharm Bull 2001;49:840-4.

36. Mosa Elhady Osman, Hanadi Hassan Yassen, Justin Deng Deng, Remaz Omar Mustafa, Saad Mohamed Hussien, General phytochemical screening and antioxidant of some sudanese medicinal plants. J For Prod Ind 2014;3:292-5.

37. Prescott LMH, Arley JP, Klein D. Microbiology (International Edition). Fifth edition. Published By Mc Graw Hill Book Company; 2002. p. 809-19. 